\title{
ペインクリニックに於ける針治療の成果
}

鳥取県 山 内 教 宏

\section{THE RESULTS OF THERAPEUTIC ACUPUNCTURE IN A PAIN CLINIC}

\section{Norihiro YamaUchi ${ }^{*}$}

THERAPEUTIC ACUPUNCTURE has been widely used for 4,000 to 5,000 years in traditional oriental medicine and acupuncture analgesia for operations has been used successfully in China since 1958. World-wide attention, however, was first focused on acupuncture by Dimond's report which appeared in $1971 .^{1}$ Although acupuncture is not yet an accepted medical procedure in Canada, the author nevertheless was invited as a Visiting Assistant Professor to show whether acupuncture might serve as an efficient method of treating chronic pain syndromes. The work was carried out in Pain Clinics at University Hospital, Saskatoon and the Plains Health Centre in Regina. Consequently exploratory trials with acupuncture were undertaken by the author between. June, 1974 and May, 1975.

\section{METHOD}

Patients were accepted for acupuncture treatment only upon referral by their family physician and after they had been examined thoroughly, often by a number of specialists in various fields and had proven themselves as not responding to conventional treatments such as medication, operation, nerve block, physiotherapy, chiropractic treatment, psychotherapy, etc. All patients suffered from chronic pain syndromes or neurologic disorders.

Acupuncture needles of stainless steel $1.2 \mathrm{~cm}$ to $6.4 \mathrm{~cm}$ in length and $0.20 \mathrm{~mm}$ to $0.32 \mathrm{~mm}$ in diameter were used depending on the location of the appropriate acupuncture points. "After use they were soaked in chlorhexidine gluconate (Savlon ${ }^{\circledR}$ ), then washed in water, packed as individual sets, and autoclaved.

Two kinds of acupuncture treatment were used in this series depending upon the condition to be treated. The first method was as follows: An acupuncture needle was inserted quickly by means of a needle holder (Figure 1 left), followed by weak direct current stimulation of 12 volts and 150-200 microamperes applied through the needle by means of a Neurometer ${ }^{\circledR}$ (Figure 2). The needle was withdrawn as soon as sensation was elicited, be this dull pain, heaviness, numbness, a tense or comfortable feeling, tingling or electric shock. Usually 20 to 40 points were stimulated by this method, which was employed mainly in treating musculoskeletal disorders, arthritis and headache.

The second method was as follows: needles (Figure 1 right) were inserted to obtain one or more of the sensations described above, but were kept in position

\footnotetext{
-Visiting Assistant Professor, Department of Anaesthesia, University of Saskatchewan, Saskatoon, Saskatchewan, Canada.

Present address: Department of Anesthesiology, Tottori University School of Medicine, 36-1 Nishi-machi, Yonago, Tottori-ken, 683, Japan.
} 


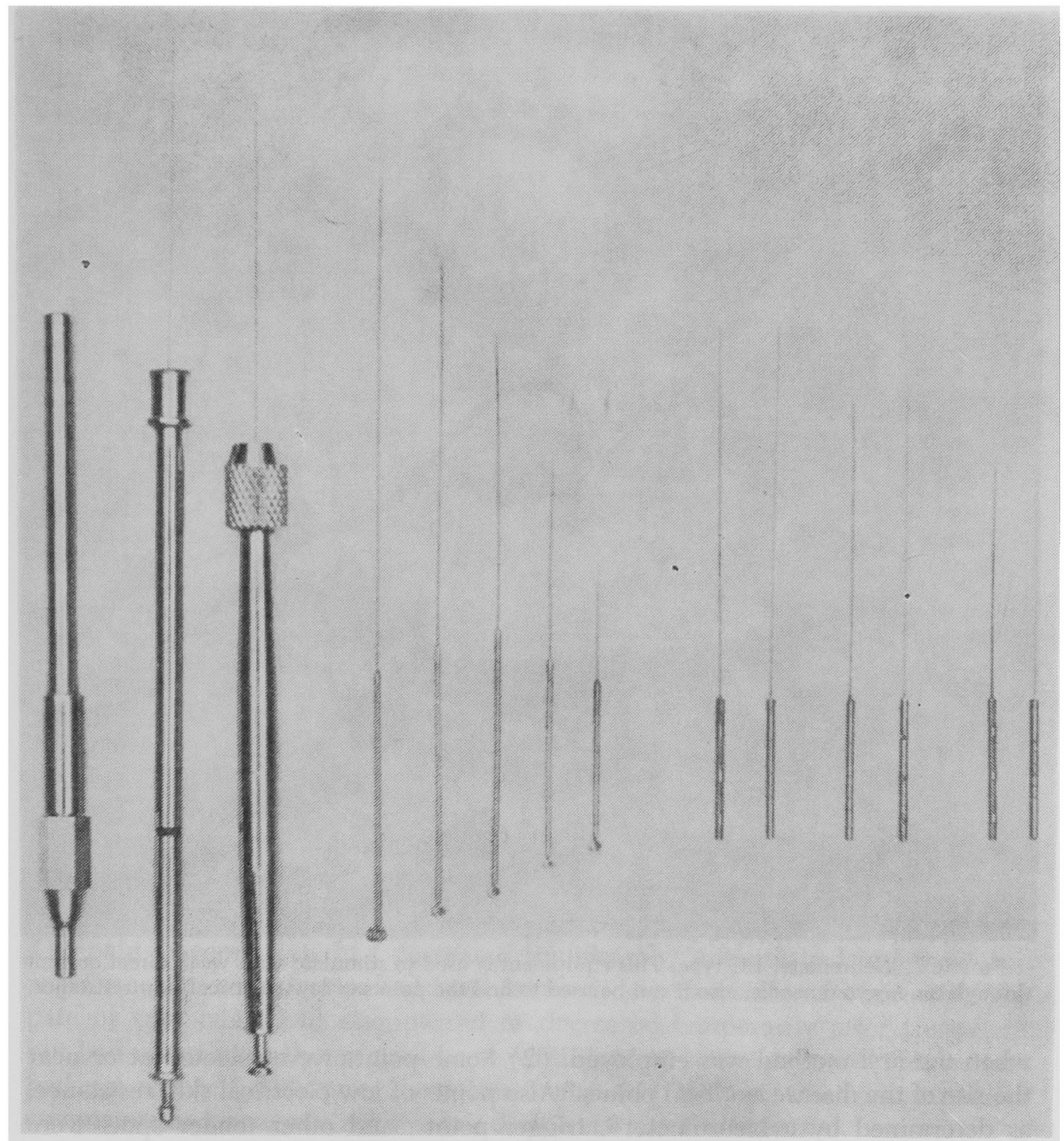

Figure 1. Acupuncture needles are made of stainless steel, $1.2 \mathrm{~cm}$ to $6.4 \mathrm{~cm}$ in length and $0.20 \mathrm{~mm}$ to $0.32 \mathrm{~mm}$ in diameter. Three needles of the left show the needles. with needle holder for "the quick insertion method," and the others of the right show the needles for. "the prolonged insertion technique."

for 15 to 25 minutes, after which they were removed.. A stimulus from a BT-701 stimulator (Figure 3), a 71-1 stimulator made in China, or by an Acoma stimulator made in Japan was applied to these needles. In most cases 10 to 20 points were stimulated by this method which was used mainly in treating sciatic pain, neuralgias, neurologic disorders and miscellaneous pain syndromes which had responded poorly to the first method.

The selection of acupuncture points was generally as follows: (1) Seventeen points (Figure 4) were selected in most cases as "general basic points" especially 


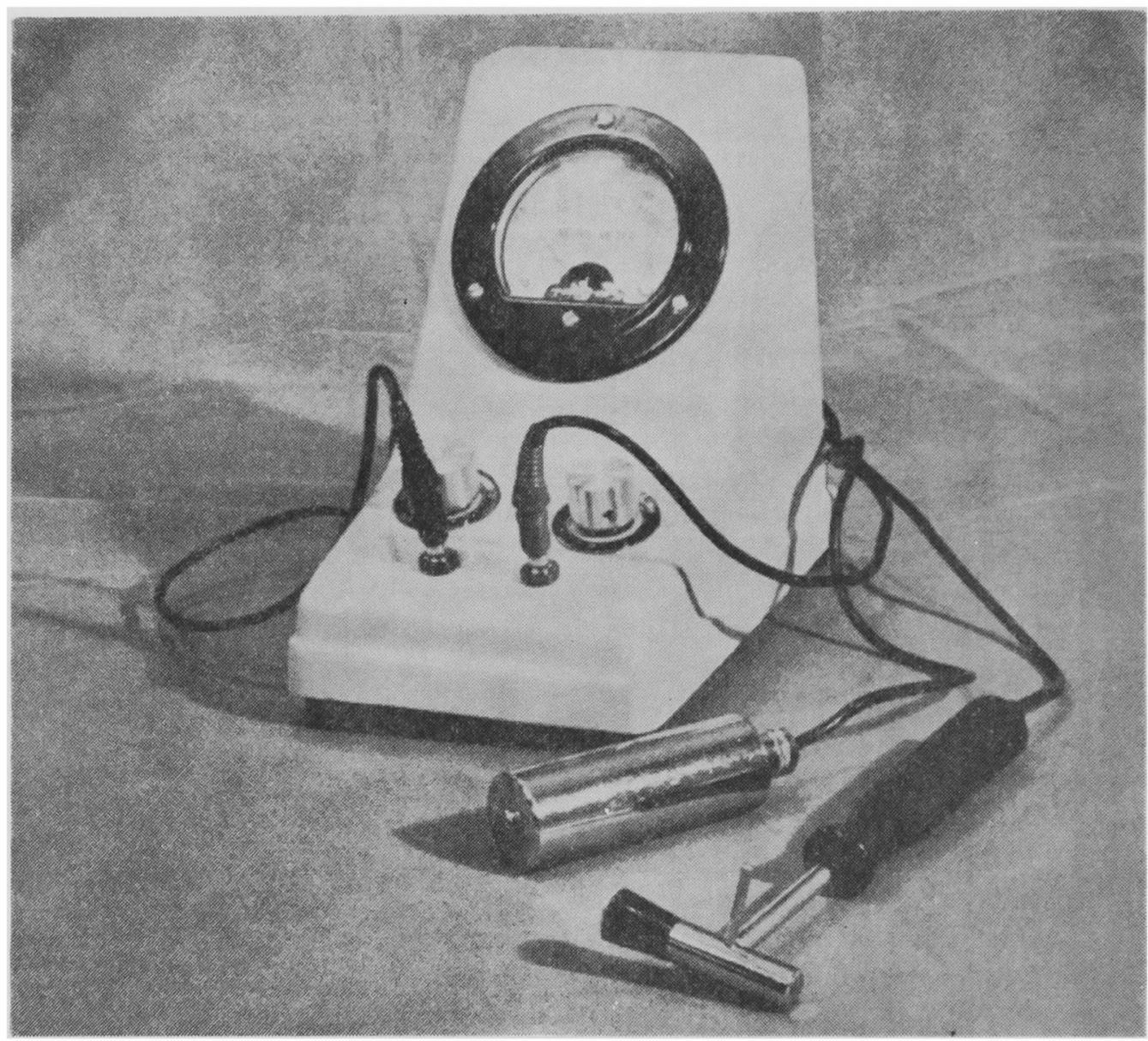

FIGURE 2. Neurometer LC type. This equipment is used to stimulate with weak direct current through the inserted needle, also it can be used to find the points of low electrical skin resistance.

when the first method was employed. (2) Some points were selected at or near the site of the disease as "local points." Also points of low electrical skin resistance, as determined by a Neurometer ${ }^{\circledR}$, trigger points; and other tender spots were used in some cases. Points of low electrical skin resistance have been called "Reactive Electro-permeable Points" (REPP) by Nakatani ${ }^{2}$ and they are considered to be effective points for acupuncture. (3) Some points which are said to be effective for a particular disease or symptom on the basis of the traditional meridian theory were selected as "specific points." (4) Lastly, points were chosen close to the nerves innervating the area of pain, similar to those used for individual nerve blocks.

Treatments were carried out from once to three times a week depending upon the compláint and were repeated until a satisfactory result had been achieved or until no further progress was made. After treatment had been terminated, posttherapeutic evaluations were done by means of the patients' own reports, by noting objective functional changes and changes in the requirements for analgesics. The criteria for evaluating results were as follows: (1) Marked improvement: The 


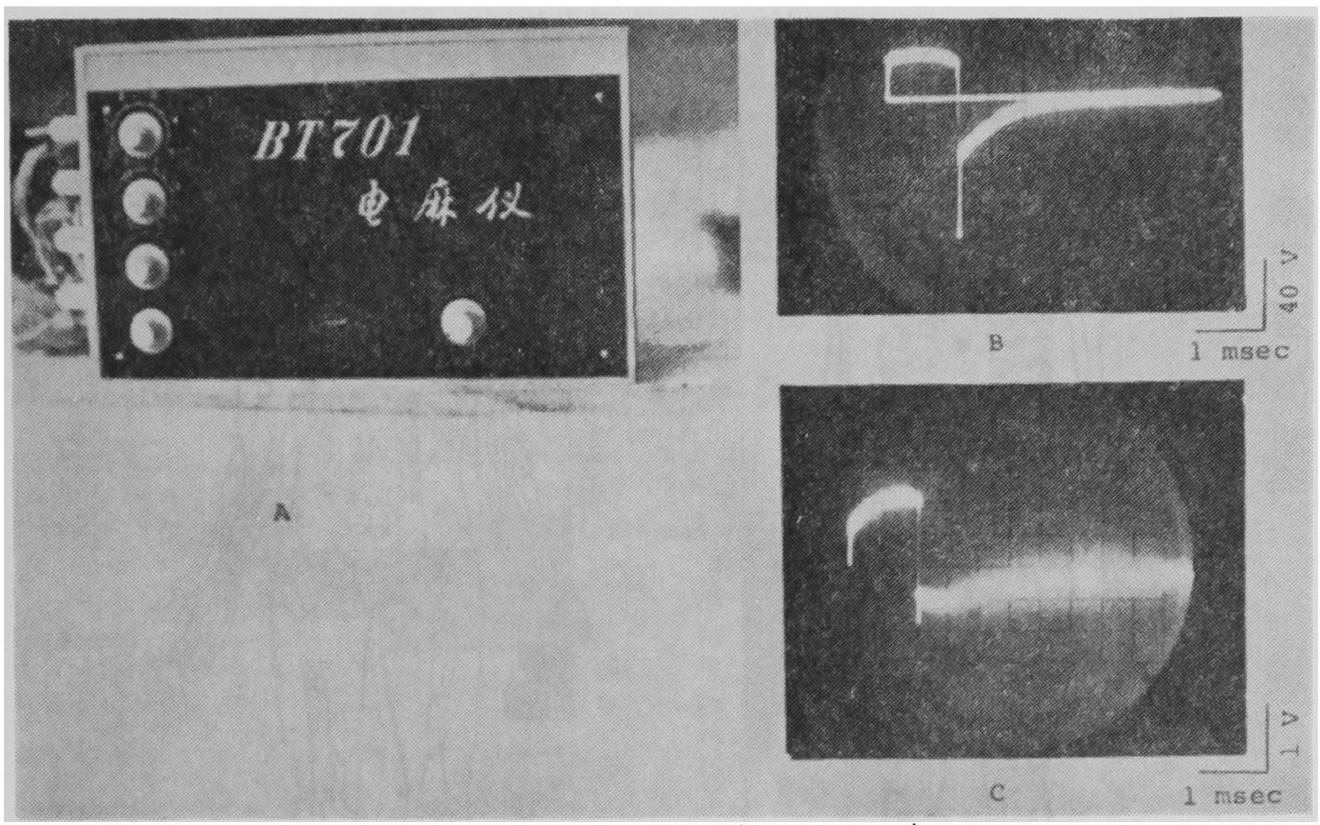

Figure 3. A. BT-701 stimulator for acupuncture analgesia. B. Electrical waveform of a BT-701 when measured without load ( 50 per cent of the maximum output). C. Electrical waveform of a BT-701 when applied during acupuncture analgesia with one pair of electrodes ( 10 per cent of the maximum output).

pain or complaints had disappeared completely, or had decreased by over. 75 per cent compared to the state before treatment. These patients could carry on with their usual activities and analgesics were no longer required. (2) Improvement: The pain or complaints had decreased significantly. Activity had improved and requirements for analgesics had been reduced. (3) Transient improvement: The pain or complaints had disappeared or decreased temporarily after treatments but had returned to the original level within one to seven days and this pattern had not changed with subsequent treatments. (4) Failure: Changes in pain or complaints had not been achieved with at least two treatments.

A questionnaire was sent to all patients in June, 1975 to ascertain the long-term effectiveness of treatment. The criteria for evaluation were as follows: (1) Marked improvement: The pain or complaints had disappeared completely, or had decreased by over 75 per cent as compared to the state before treatment. (2) Improvement: Pain or complaints had decreased significantly. (3) Failure: Pain or complaints had not changed appreciably, while temporary relief might or might not have occurred. (4) Deterioration: The pain or complaints had increased compared to the state before treatment.

\section{RESULTS}

Seventy-two patients received a total of 606 acupuncture treatments during .a 12 -month period. Of these, 318 treatments ( 52.5 per cent) were by "the quick 

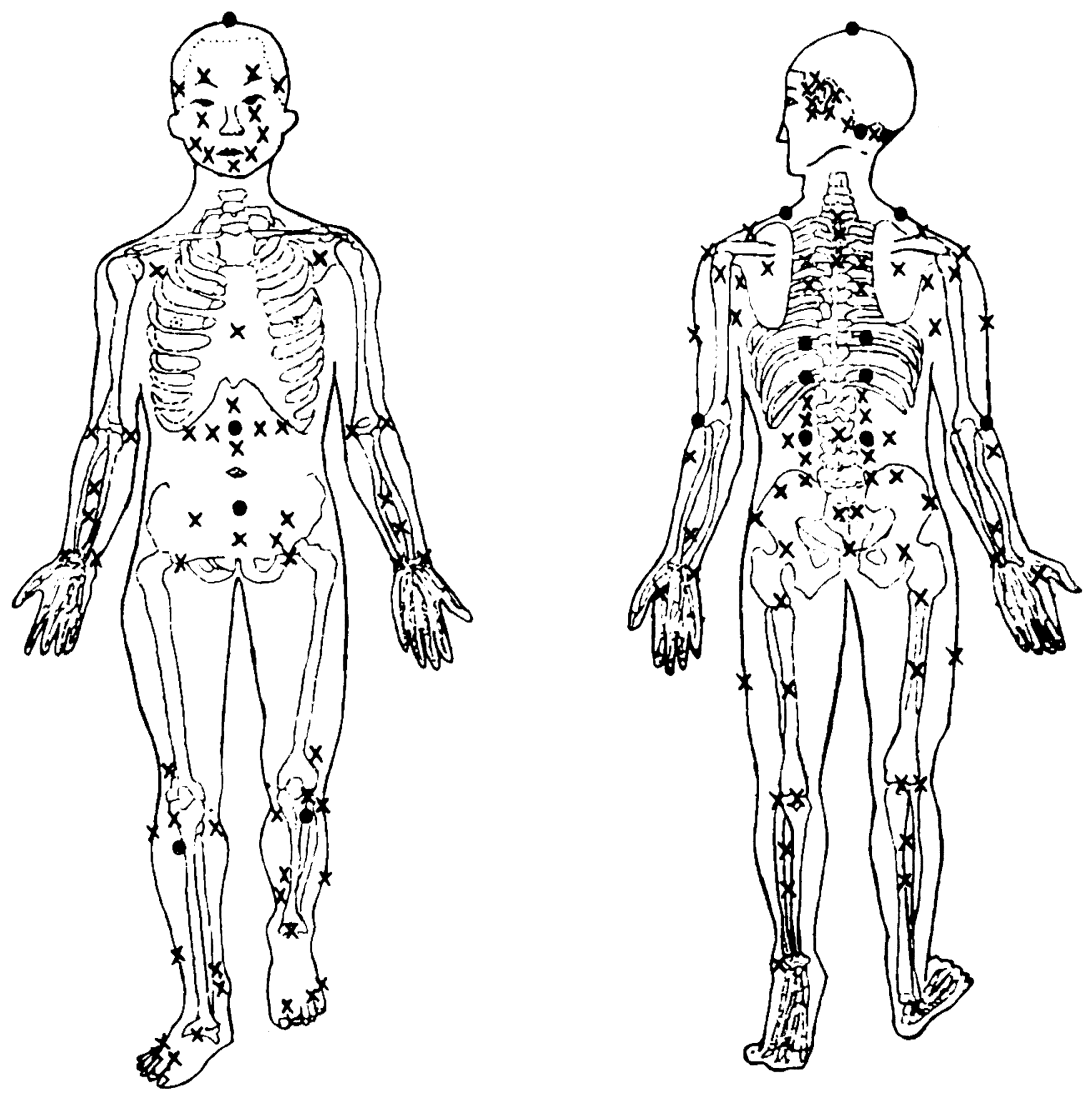

Figure 4. Acupuncture charts. General basic points (17 points). $\times$ The points which are used frequently by the author ( 140 points).

insertion method," while 249 treatments ( 41.1 per cent) were by "the prolonged insertion technique" and 39 (6.4 per cent) by both methods combined.

The distribution of age, duration of pain or complaints before their first visit to the Clinic and number of the treatments are shown in Figure 5. Forty-two patients ( 58.3 per cent) were male and 30 ( 41.7 per cent) female. The mean age of our patients was $51.9 \pm 13.8$ years, the mean duration of pain or complaints $8.0 \pm 8.4$ years and the mean number of treatments per patient $8.4 \pm 5.8$.

The diagnosis, immediate and long-term results are shown in Table I. At the conclusion of treatments, marked improvement had been obtained in 19 cases (26.4 per cent), improvement in 20 (27.8 per cent), transient improvement in 21 (29.1 per cent) and in 12 patients ( 16.7 per cent) treatment had failed.

Long-term results were obtained by questionnaire at two weeks to ten months (mean $3.7 \pm 3.0$ months) after the final treatment. Analysis showed that marked improvement had been achieved in 11 cases ( 15.3 per cent), improvement in 20 (27.8 per cent) and failure was encountered in 25 cases ( 34.7 per cent), while four patients ( 5.5 per cent) were worse. No response to the questionnaire was obtained from 12 patients ( 16.7 per cent). 

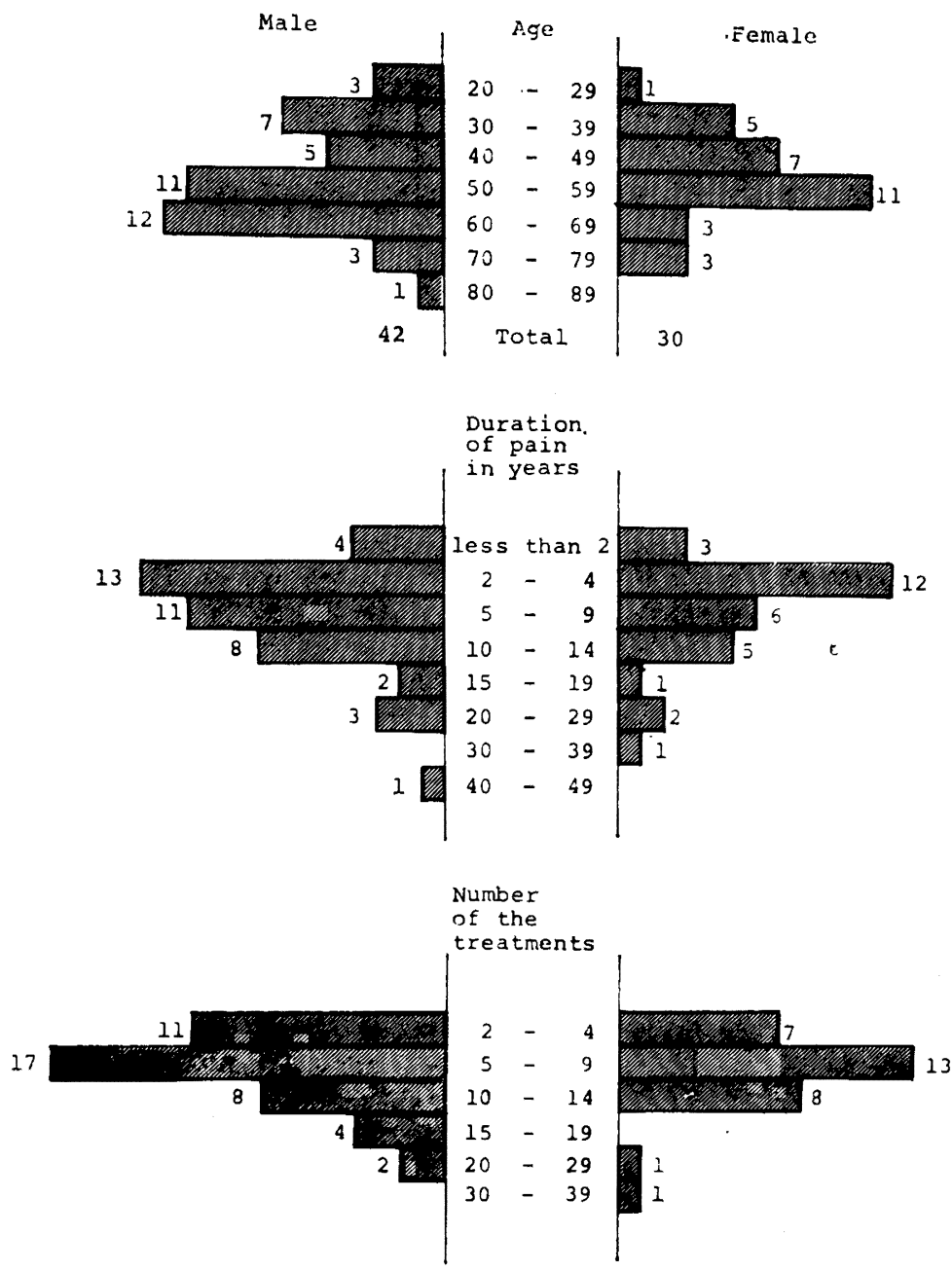

Figure 5. The distribution of age, duration of pain or complaints before their first visit to the Clinic and number of the treatments.

\section{a) Musculo-skeletal disorders}

Thirteen patients with a variety of musculo-skeletal disorders were treated. Four ( 30.8 per cent) showed marked improvement and another 4 were improved in the long term.

\section{b) Low back and leg pain}

Six patients with low back and leg (sciatic) pain were treated. One (16.7 per cent) showed marked improvement and one had long-term improvement.

c) Arthritis

Fifteen patients in this group were treated. Three (20.0 per cent) showed marked improvement and 7 ( 46.7 per cent) had improvement in the long term.

d) Headache

Seven patients with headache were treated. Two ( 28.6 per cent) showed marked improvement and 3 (42.9 per cent) were improved in the long term. 


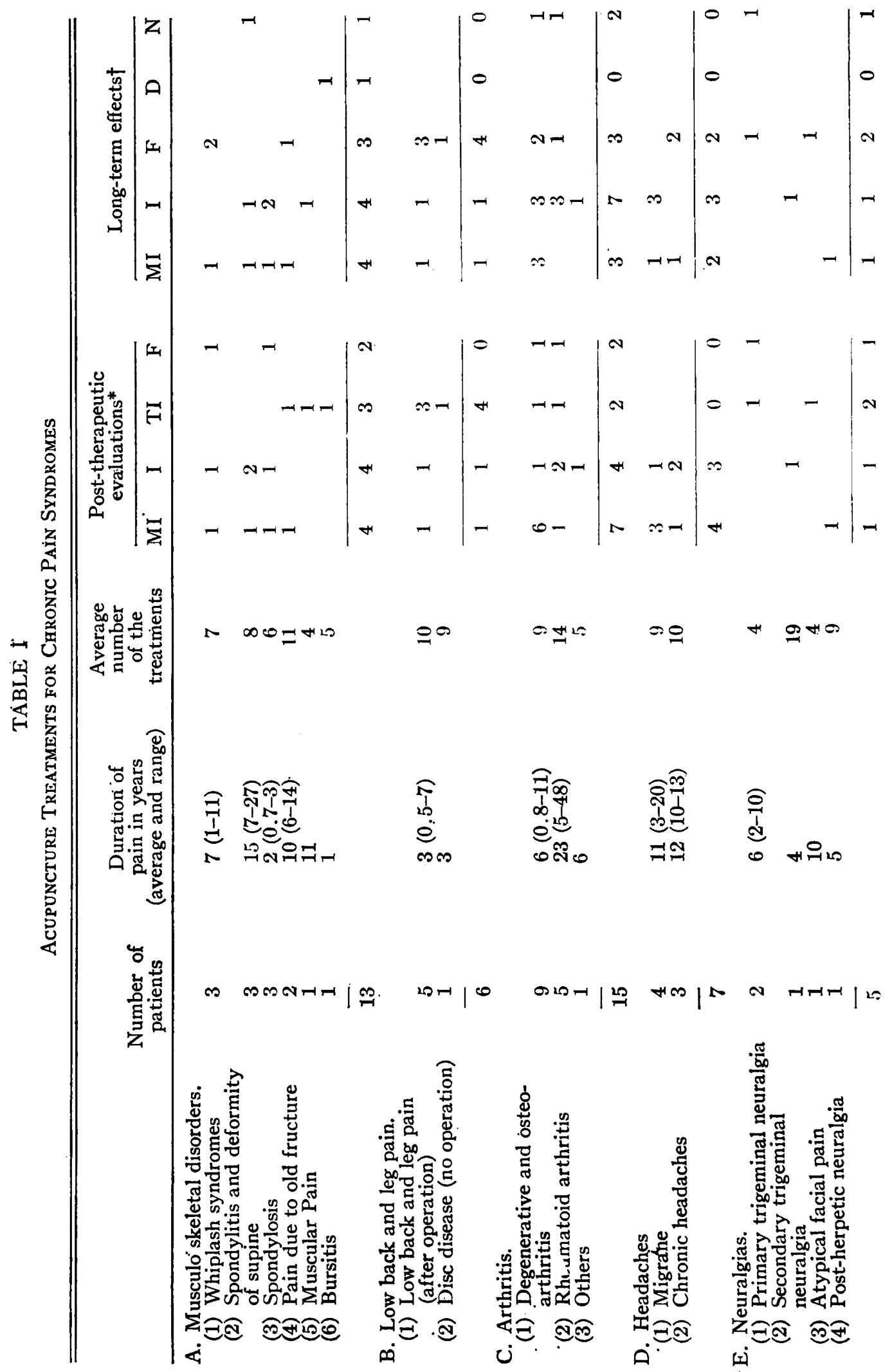




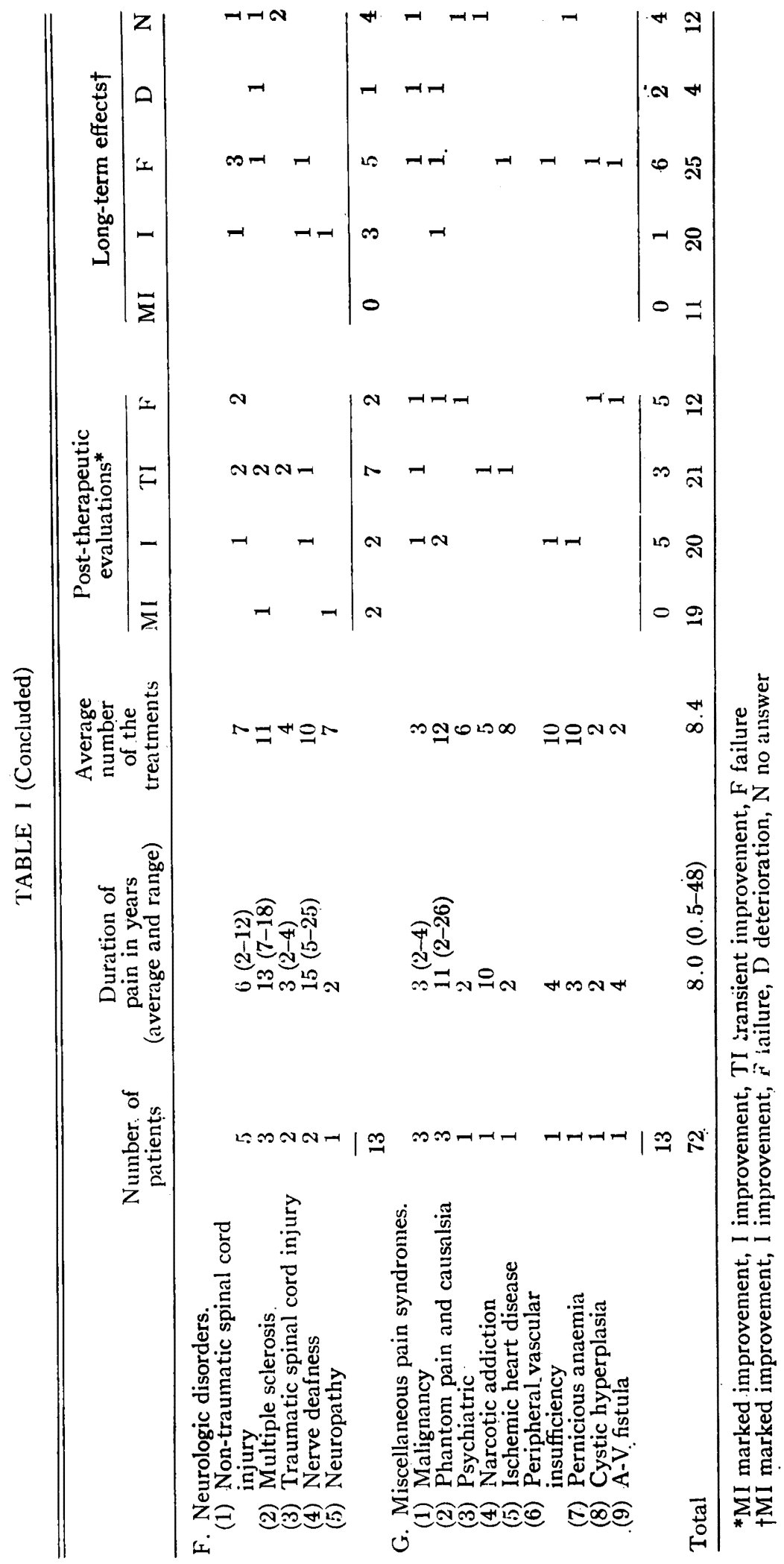




\section{e) Neuralgias}

Five patients with a variety of neuralgias were treated. One (20 per cent) showed marked improvement and one had long-term improvement.

\section{f) Neurological disorders}

Thirteen patients with a variety of neurological disorders were treated. Three (23.1 per cent) showed long-term improvement.

g) Miscellaneous pain syndromes

This group consisted of 13 patients with various pain syndromes. Only one ( 7.7 per cent) had long-term improvement.

\section{Discussion}

There have been few reports giving results of acupuncture treatment in the Western world. Spoerel and Leung ${ }^{3}$ have achieved pain relief in 94 per cent of 111 patients who had chronic pain conditions not associated with malignancy. Lieung, et al. ${ }^{4}$ have reported 2,041 acupuncture treatments in 3.57 patients with a wide variety of conditions over a period of 12 months, and have obtained complete relief in 53 patients ( 14.8 per cent) and partial relief in 159 patients ( 44.5 per cent). Barke ${ }^{5}$ has reported 13,265 acupuncture treatments in 5,000 patients during a six-month period and 86 per cent of his patients had some degree of relief. Our own post-therapeutic evaluations showed that 26 per cent had marked improvement, 28 per cent had improvement and 29 per cent were improved transiently. These results are not as good as those of Spoerel and Leung, ${ }^{3}$ but they are closely. similar to the results of Leung, et al..$^{4}$ and Barke. ${ }^{5}$

No report of the long-term effects of acupuncture treatment could be found: A questionnaire was sent to the 72 patients to obtain this information. There are many difficulties associated with such a follow-up study and, indeed, no answer was obtained from 12 patients. The results obtained from the remaining.patients showed that the percentage of "marked improvement" had decreased from 26 per cent to 15 per cent but the percentage of "improvement" had remained unchanged ( 28 per cent) from the immediate post-therapy evaluations. In this study the response to acupuncture treatment for each of seven categories of diseases was broken down into three stages on the basis of the percentages of long term marked improvement and improvement: (1) Good: Over 50 per cent marked improvement and improvement. (2) Fair: Percentages of 30 to 50 per cent. (3) Poor: Less than 30 per cent. On this bașis good responses were obtained in patients who suffered from musculo-skeletal disorders, arthritis, especially degenerative or osteoarthritis, and headache. Fair responses were obtained in patients with sciatic pain and neuralgias.. Patients with neurologic disorders and miscellaneous pain syndromes responded poorly.

Bonica ${ }^{6}$ has suggested that well-controlled clinical studies, which would include the use of a control group of patients treated by well-established therapy, should be conducted. The author agrees with this proposal but a control study could not be done because of limitation of time.

It is generally said that acupuncture presents no danger, but Bonica ${ }^{6}$ has pointed to the possibility of various complications and recently pneumothorax and various 
other complications have been reported. ${ }^{7-11}$. No major complications were encountered in this series other than an occasional small haematoma, followed in one case by a mild brown pigmentation. Acupuncture can be associated with pain which at times has been known to be quite uncomfortable. Six patients did not return after the first treatment and were not included in this study.

The phýsiological mechanisms underlying acupuncture are still unknown, but hypothetical explanations have been offered on the basis of neurological, humoral and meridian considerations. The author together with co-workers ${ }^{12}$ have reported that somatosensory evoked potentials are reduced in amplitude by electrical acupuncture analgesia given to the ipsilateral side and that spontaneous brain waves showed electroencephalographic changes especially of the alpha wave.

In conclusion, acupuncture can be used to manage various conditions of chronic pain for which conventional Western treatments are less effective. Acupunctiure is relatively easy to learn and to practice by the acquisition of even minimal knowledge of the technique.

\section{SUMMARY}

Acupuncture has been used to treat various conditions of chronic pain in a pain clinic. Six hundred and six acupuncture treatments were administered within the space of 12 months to 72 patients who had not responded well to conventional treatment. At completion of the acupuncture treatments 19 patients showed marked improvement, 20 showed improvement and 21 transient improvement.

Long-term results were also investigated at a mean of four months after the final treatment. The results of this follow-up study showed marked improvement in 11 patients and improvement in 20 others. In terms of conditions treated, best responses were obtained in patients with musculo-skeletal disorders, degenerative or osteoarthritis and headache.

\section{RÉSUMÉ}

L'acupuncture a été utilisée pour traiter divers problèmes de douleur chronique dans une clinique de douleur. Soixante douże malades qui n'avaient pas eu de boǹs résultats avec des méthodes conventionnelles: ont reçù un total de 600 traitements d'acupuncture durant une période de 12 mois.

En fin du traitement à l'acupuncture, 19 malades avaient un résultat qualifié d'excellent, 20 malades étaient améliorés et 21 autres avaient eu une amélioration temporaire.

On a également évalué les résultats à long terme (en moyenne quatre mọis après la fin du traitement). On a retrouvé une amélioration marquée chez 11 patients et une amélioration chez vingt autres malades.

Les meilleurs résultats ont été obtenus chez les patients présentant des douleurs d'origine musculosquelettique, chez ceux présentant de l'ostéo-arthrite ou de l'arthrite dégénérative et dans les cas de céphalée.

\section{ACKNOWLEDGMENTS}

The author wishes to acknowledge the co-operation of the medical staffs of 
University Hospital, Saskatoon and Plains Health Centre, Regina, University of Saskatchewan. Particular thanks are due to Tr. G.M. Wyant, $\Omega_{r} \boldsymbol{C E}_{\text {. Hope and }}$ Dr. W.B. MacDonald for arrangements and advice, and.to Dr. L.J. Clein and Dr. A.R. Kirby for their help with this study. The assistance of the Grrornment of Saskatchewan is gratefully acknowledged for having made available funds in support of this Visiting Professorship.

\section{REFERENCES}

1. Dimond, E.G. 'Acupuncture anesthesia. J.A.M.A. 218: 1558 (1971).

2. NAKATANI, Y. A guide for application of ryodoraku äutonomous nerve regulatory therapy, 1st ed. Tokyo: Japan Ryodoraku Autonomic Nervous System Society (1972).

3. Spoerel, W.E. \& Leung, C.Y. Acupuncture in a Pain Clinic. Canad. Anaesth. Soc. J. .21: $221(1974)$.

4. Leung, S.J., Fan, C., \& Sechzer, P.H. Acupuncture therapeutics. Anesthesia and Analgesia 53: 942 (1974):

5. BARKE, M.W. Acupuncture - a preliminary report. J. of Kynto Dain Control Instaiute 7: 128 (1974).

6. BonicA, J.J. Therapeutic acupuncture in the People's Republic of China. J.A.M.A. 228: 1544 (1974).

7. Carron, H., Epstein, B.S., \& Grand, B. Complications of acupuncture. J.A.M.A. 228: 1552 (1974).

8. KuIPER, J.J. Pneumothorax as complication of acupuncture. J.A.M.A. 229: 1422 (1974),

9. Drake, T.E. Complication of acupuncture. J.A.M.A. 229: 1285 (1974).

10. SMITH, P.F. Complication of acupuncture. J.A.M.A. 229: 1286 (1974).

11. Hussain, K.K. Serum hepatitis associated with repeated acupuncture. British Medical J. 5922: 41 (1974).

12. Yamauchi, N., Okazaki, N., Sato, T., Fujitani, Y., Kuda, K., Onkawa, T., \& Úchma, Y. The effects of electrical acupuncture analgesia on human somatosensory-evoked potentials and spontaneous brain waves. Am. J. Acupuncture (accepted for publication)

（表紙 3 よりつづく）

と必ず名称して鿓うよう区別する。

\section{1. 会則変更}

以上のととより会則の改正変更を行う。特に 会費は従来通り年額 85,000 としてその中より 支部補金を支給していたが、てれを排して会費 の実質的值上げとす。また入会金は 55,000 と して、良導絡学の一定の講習をうけて正しい良 導絡治療の原理と技術を習得せしめて、会員証 を授与するものとする。また本会への寄付等の 項目をとり入れるため、維持会費一口孔10,000 を新設する。

学会々則に関しては充分検討を要するので本 年度期間（51年 4 月より 52 年 3 月 31 日）までに

審議を重ねて作成するすのとする。

以上の各項については各自地区にもちかえり その地区にて再検討して、変更を要する項目ま たは未決定の項目に関しては第28回学会までに 本部に通告決定するむのとし、すべての処理に 関しては主催地役員によって処理をまかせ、本 会発展のため一層の努力を払うととを申し合せ 盛会裡に閉会した。

\section{出席者 中谷先生}

東日本側 及川、斉藤、関、熊谷、成宮 西日本側 小林、吉田、山崎、大塚、石見 鳥山、円山、田中、塩川、黒田 伊丹、岸本、津山 